\title{
Sensus communis: The relevance of Medieval philosophy in the 21st century
}

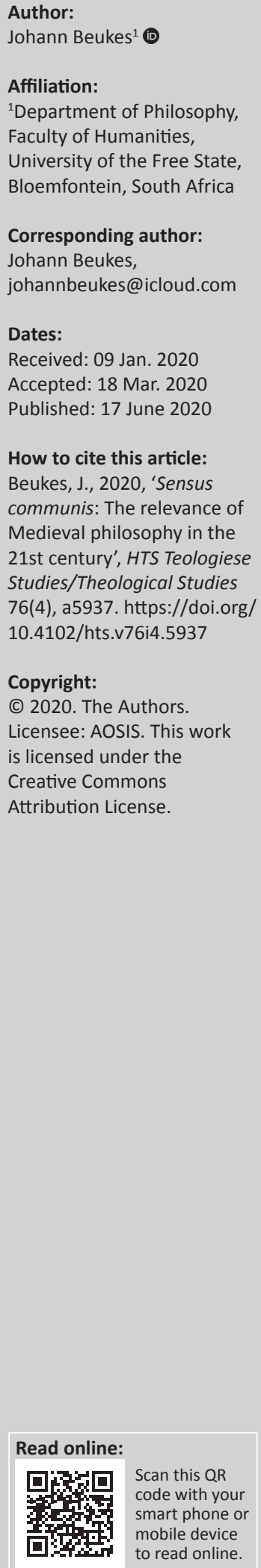

This article addresses the underestimation of Medieval philosophy in the contemporary curriculum by engaging its very origins in the 'postmodern' dislocation of philosophy. The leading question is what would be the prospects in the 21st century of reorienting Western philosophy from its idea-historical sources, which would include its ancient traditions and the Medieval exposition, as well as the Renaissance elucidation thereof. Critically engaging the works of numerous 'postmodern' philosophers (Lyotard, Derrida, Foucault, Baudrillard, Virilio and Zizek) as well as critics of the 'postmodern' departure from traditional philosophy (Gadamer, Habermas, Jameson, Norris), this article argues for the re-establishment of the late Medieval notion of sensus communis, both as common sense and community sense. Against this backdrop, the article reappraises Medieval thought within the context of sensus communis to combat the contemporary dislocation of philosophy, by raising the possibility of the presentation of first-order judgments via sensus communis in a new pursuit for wijsbegeerte.

Keywords: Jacques Derrida; Umberto Eco; Michel Foucault; Hans-Georg-Gadamer; Martin Heidegger; Fredric Jameson; Jean-Francois Lyotard; Medieval Philosophy; Christopher Norris; Sensus communis; Paul Virilio; wijsbegeerte; Slavoj Zizek.

\section{Of your philosophy you make no use \\ If you give place to accidental evils \\ - Shakespeare, Julius Caesar}

\section{'The darkening of the world and the flight of the gods'1}

Martin Heidegger's ${ }^{2}$ notorious statement about the 'darkening of the world and the flight of the gods', juxtaposed with the author's most recent work in Medieval philosophy, ${ }^{3}$ serves as the discursive basis for this article. Is it, against the backdrop of Heidegger's intuition, justified to ask: is Western philosophy not supposed to provide more than what it currently is affording - or exactly not affording? Has Western philosophy, which once was able to distil only the best from the human faculties, become so depleted, to the point of utter liquidation, that it is now seemingly little more than a 'deconstructing language-game'? Flanking Umberto Eco, ${ }^{4}$ a second question is put forward: what are the prospects in the 21st century of reorienting Western philosophy from its idea historical fonts and sources, which would include its ancient traditions and the Medieval exposition as well as the Renaissance elucidation thereof? A third question applies: what designate the locus and status of the many long-elapsed and derelict thinkers, themes and moments in philosophy and has the time not finally arrived to preserve philosophy, precisely by defending philosophy against itself, via a relentless perseverance in the search for frameworks of a stronger conceptual discipline, than what is presently offered in this 'matrix of all noteworthy scientific disciplines'? ? $^{5}$ the epoch of systematised terror as the most dominant social marker in the West in the 21st century, should philosophy not be a sanctuary of sobriety rather than a playground for sardonic and quasi-satirical jesters, for whom not even the most acute epistemologies of terror are \footnotetext{
1.The author is an associate of the Center for the History of Philosophy and Science (CHPS), Radboud University Nijmegen, The Netherlands.
}

2.Heidegger (1985:37).

3.See Beukes (2018a-d; 2019a-f; 2020a-j).

4.Eco (1997) stated, somewhat controversially for some at the opposite end of the philosophical weighbridge, that:

It would hardly be a waste of time if sometimes even the most advanced students in the cognitive sciences were to pay a visit to their ancestors. It is frequently claimed in Philosophy departments that, in order to be a philosopher, it is not necessary to revisit the history af philophy. It is like the claim that one of philosophy. It is the class. Such thine care themen having ever read the classics. Such things are theoretically possib; but the 'primitive' artist, conde w ways recognizable as such and rightly labelled as naif. It is only when we consider past projects revealed as utopian or as failures that we are apprised of the dangers and possibilities for failure for our allegedly new projects. The study of the deeds of our ancestors is thus more than an antiquarian pastime; it is an immunological precaution (p. 5).

5.Beukes (2005:1101-1105) 
presenting an impetus for a rehabilitation of clear-headedness in philosophy?

Has philosophy, especially with its 'postmodern' façade in this devastating epoch of systematic error, finally lost its venerable standing as the life-giving cradle for social and moral bearing? Against the catastrophic backdrop of gradual and indeed progressive (the more, the more vicious) acts of terror in the West in the first two decades of the 21st century, should not philosophers at least endeavour to confront the many paradoxes, self-contradictions and the accompanying sublimation of brutality, springing forth from those 'deconstructive' kind of statements, buzzing that nothing can really be taken seriously in the 'traditional' philosophical realm any longer? Is this philosophy's answer to New York and elsewhere on 11 September 2001, Madrid on 11 March 2004 (and in chronological sequence, Stockholm on 11 December 2010, Boston on 15 April 2013, Paris on 07 January 2015 and even more brutal on 13 November 2015, Brussels on 22 March 2016, Berlin on 19 December 2016, Manchester on 22 May 2017, London on 03 June 2017 or Barcelona on 17 August 2017, to name just a few prominent of the many more slayings in and attacks on the West)? If these events cannot be taken seriously in the traditional philosophical sense, then the question is what can? Because if it is indeed true that philosophy has become so bankrupt that it refuses to address pure terrorism or even worse if it has become an apologetic agent for terrorism, it is true, then that philosophy is dead and has become utterly obsolete.

In a time when philosophy should be impacting the lifeworld system with conceptual lucidity and the sort of forensic meticulousness Michel Foucault so obstinately insisted upon, she is seemingly dumbstruck and lamentably unconnected to the world. We either have to accept this as a given and inexorable fact - or we can fight back and not being so smug and self-righteous about it. The author's refusal to accept the 'postmodern compulsory' implies a new sense of Medieval scholastic eu legein or contemporary Foucaultian parrhesia: the ability to speak frankly about all matters that have always intrigued philosophy since the pre-Socratics, matters that involve truth, beauty and justice in particular. The parrhesian space is to be found somewhere between the flash and the void, somewhere between the dazzling thinkers of antiquity and their dull modernist counterparts: thus, in the Middle Ages, which was a millennium-long epoch of which at least seven centuries bear witness to the production of the highest volume of conceptual outputs detailed in the Western history of ideas.

However, reading Medieval philosophy as a contra-modern and a particular contra 'postmodern' appraisal poses at least one hermeneutic prerequisite: it would have to come forth out of a longing and intense desire for wisdom, which constitutes a curiously longstanding spur for the Western practice of philosophy. This is philosophy in an old-worldly and today perhaps an 'otherworldly' sense of the word: not translatable in English, this is wijsbegeerte, the practice of philosophy, without any instrumental or economic objectives for some immediate applicability, as presented in the formidable Dutch scholar of Medieval philosophy, L.M. de Rijk's work, ${ }^{6}$ where philosophy is always 'bound to tradition' yet always 'prepared to engage' the contemporary world with the always-relevant and invigorating tools of philosophy in hand.

This desire for wisdom, as Boethius' Lady Philosophy in De consolatione Philosophiae (1934) stressed, appreciates fate but is not determined by it. Free will is neither determined and eliminated nor undermined by philosophy. The philosopher's most profound consolation should be that he or she can always still act and react, whether roaming the countryside or bound in balls and chains. Lady Philosophy's consolation is in this sense a predecessor of the most remarkable desire for philosophy in the perspectives of the first female philosopher of the Middle Ages, Héloïse d'Argenteuil (ca. 1100-1164), who, in her 'Ciceronian-posed love' as the mistress, reluctant wife and soulmate of the greatest dialectician of the 12th century, Peter Abelard (1079-1142), posited that the love for philosophy and the love for the one true soulmate is one and the same: 'radically uneconomical', with love not a means to anything and with no instrumental value whatsoever, but rather a constant and self-affirming gift, in terms of which the only objective of love is to 'bring to expression the metaphysical best in the Other'.?

Wijsbegeerte is precisely this: the desire to bring to expression the metaphysical best in the discipline of philosophy, yet dialectically to be loved and transformed by philosophy so that she brings to expression the metaphysical best in her philosophers. Without this love and desire for wisdom and this wisdom's reciprocal love, philosophy is not possible. Then it is indeed nothing but a technical if not 'analytical' discipline, which will never have more to offer than dubious claims to 'applicability' and brute instrumentalism. Moreover, if philosophy is merely a technical, 'applicable' discipline, the dislocation, if not the dissolvement of philosophy, will follow quite spontaneously.

\section{The dislocation of philosophy}

However, the Ciceronian love for philosophy and to dialectically be loved by philosophy certainly is not the hallmark of contemporary philosophy. Philosophy has been severely dislocated over the past five decades, and the roots of this dislodgment can be traced back to developments in French philosophy in particular from the early 1960s onwards. Not all these developments have been counterproductive to philosophical practice in the wijsgerig sense of the word: Michel Foucault, for instance, who was initially labelled as one of the French 'post-structuralists' of the 1960s but who took leave from that label very quickly, profoundly changed the way we consider social structures, social veracities, language, knowledge, discipline, punishment, medicine, insanity, sexuality, science, historicity, religion and,

6.For example, De Rijk (1977)

7.D’Argenteuil (1855:183); see Cicero (1914:xiv) 
most important, the structure of Western philosophy itself. Foucault had an irreversible impact on contemporary philosophy and never partook in the displacing of it. His legacy is certainly not under scrutiny here.

Yet, whose is then? To answer this question, one has to understand quite thoroughly what transpired in French philosophy after the demise of existentialism in the late 1950s. Two evident phases could be specified in this period: the first, structuralist-driven phase brought radically new themes into the time-honoured dome of philosophy. Of these themes, three, in particular, stand out: the interrogation of objectivity, the decentralisation of the acting subject and the self-critical attempt to move beyond traditional epistemologies in philosophy as we knew it. The presentation of these three themes still took place within the much older parameters of French positivism.

The second phase was much more complex than the first and can be regarded as either the initial phase of post-structuralism or the last phase of structuralism (accordingly labelled 'latestructuralism') and had but one objective: precisely the annihilation of positivism, in terms of which reality can be positively known, via the objectification, reification and strict scientific explanation of reality. The critical reappraisal of the three themes in the first phase in this initial phase of poststructuralism or late-structuralism gave way to what would manifest itself just more than a decade later as 'postmodernism', in the work of Jean-Francois Lyotard in particular. Jacques Derrida, Roland Barthes and Julia Kristeva could be included in this 'post-structuralist domain' as well. It is significant that neither Foucault nor Derrida nor any noteworthy philosopher preceding Lyotard gave any preference whatsoever to the concept postmodernism or showed any affinity towards this dubious concept. The 'poststructuralists' all very quickly went their idiosyncratic ways, Foucault (inasmuch as he was 'post-structuralist') with his archaeology of knowledge and Derrida, with his articulation of the critical and strained (non-)domain of difference. ${ }^{8}$

However, another trajectory was developing just after Lyotard established himself as the philosophical spokesperson of what now had become infamously swift (and therefore without proper and critical dissemination) as postmodernism. This was not the post-structuralist trajectory, but precisely a reaction against this initial reaction against structuralism. Lyotard coined ${ }^{9}$ the concept postmodernism in his The postmodern condition, published in French in 1979 and in English in 1984, in which he postulated a content which is overtly well known, arguing that the three great master narratives or metanarratives of modernity have become entirely exhausted: the Enlightenment's claim to progress (with all its initial emancipatory potential), the teleology of idealism and the historicism of modern hermeneutics. It is significant that for Lyotard, it is not merely the contents and claims of these three master narratives that have been 8.See Beukes (1996, 1998, 2002a, 2009a \& 2009b).

9.Lyotard (1984:1-32). exhausted by the modern project itself, but that the contexts in which these contents and claims were (and are) received had drastically changed after the Second World War. The universal nature of these claims was unmasked, accompanied by a simultaneous confrontation with diversity in the lifeworld system itself. ${ }^{10}$

In social guise, these radically changed contexts of reception deal with what Lyotard $^{11}$ called a 'post-industrial, computerized, digitalized and image-mediated' environment, where notions of cultural embeddedness, own time, own place, particular place and geometrical space have spectacularly changed: in fact, according to Lyotard, they had become contexts of altered subjectivity. No 'facts' regarding culture, own place, history or the future are longer presentable, but mere narratives about it, supplemented by flashing and distorted images, fragments and singular narratives. The mediating impact of the acting subject and the language of the knowing subject are now being circumvented. With the annihilation of the master narratives only the singular narrative, the unassertive tale, that particularised narrative of discontinuous images and flotsam remains, with the now decentralised subject on the margins of epistemology thrust forward by a mere 'figural energy'.

This tone in Lyotard's philosophy - or whatever remained 'philosophical' about it - was immediately problematised, already in the foreword of the English translation of The postmodern condition, in which the renowned literary theorist Fredric Jameson ${ }^{12}$ confronted Lyotard for showing no interest in the legitimate claims of what can be called a 'French postMarxism'. According to such post-Marxist perspective, the master narratives of modernity is not annihilated as Lyotard insisted, but they went underground and simply acquired a 'subversive character', in terms of which power and control over concepts such as truth and justice still are capitalist in orientation, but by being subversive, not recognisable as such. The profitable monopolisation of information by ultracapitalist companies such as Microsoft and Apple is, according to Jameson, ${ }^{13}$ the clearest example of this new attempt to control truth and justice, but now in a camouflaged sense, as something that has to do with the nimble flow of information, intervallic yet incessant images and instantaneous communication - in the end, with mere perceptions of truth. Jameson notes on the basis of Lyotard's disinclination to appreciate this repressed quality of control over truth and justice in the 'epoch of the image', the era Jameson characteristically refers to as 'late capitalism', that Lyotard himself has never taken leave of modernity, but is unintentionally still deeply embedded in the basic tenets of modernism. Lyotard does not spot the proficiency of the master narratives, which he distinguished, to camouflage itself under the placard of information, communication and eventually 'mere perceptions'. In short, Jameson asserts that

10.Beukes $(2002 \mathrm{~b}: 283-290)$.

11.Lyotard (1984:xxiv)

12.Jameson (1984:x).

13.Jameson (1984:xiii) 
epistemology after Lyotard had to make room for 'perceptology'. Truth had to make room for an imagesmokescreen of truth, and justice, indisputably the central Marxist keynote, had to make room for image-correlated and cunning perceptions about justice.

Of course, Jameson is, as a pertinent materialist thinker in the Marxist tradition, fervidly opposed to this perceptological perspective on truth and the 'figural dissemination of knowledge'. That is why Jameson in his later works ${ }^{14}$ meticulously argued that the notion of truth as an 'image' or a 'perception', thus in a fixed position to be digitalised and capitalised, must be the logical consequence of Lyotard's analysis. This means quite clearly that truth and justice itself will become progressively less important, and perceptions and manipulations of central concepts in Western philosophy, such as truth and justice, will increasingly become more evident and significant.

However, one may differ with Jameson's Marxist framework, and his warnings with regard to a post-Lyotardian capitalisation of truth, using the expansion of information and the relentless image, is - and not only retrospectively so - spot-on. The author certainly is not the only modern-critical and pertinently non-Marxist thinker who welcomed Jameson's forewarnings, at the time, yet ever since-especially ever since. For instance, Jameson's critique of Lyotard resonates with the mesmerising British philosopher Christopher Norris ${ }^{\prime 15}$ identification and rebuttal of the malaise, cynicism and political apathy which have characterised the critique of culture of the post-Lyotardian, so-called 'postmodern discourse'. ${ }^{16}$ In his notable work, What's wrong with postmodernism - Critical theory and the ends of philosophy, in a chapter significantly titled Lost in the funhouse, Norris ${ }^{17}$ scrutinises the loss of sobriety with regard to conceptual analysis, method and philosophical ardour which has developed after Lyotard in the French and broader Western-European intellectual milieu.

Norris' resistance to the philosophical trajectory, which has been conveyed out of Lyotard's futurological culture analysis, could be précised in the concept innuendo. With this awkward concept, Norris indicated that themes had been progressively imported into the traditional philosophical index - which did not any longer adhere to logic, evaluation and dissemination, but on 'perceptological lobbying'. Truth accordingly vests in 'consensus' and 'consensus-values', specifically under the façade of image-driven lobbying, where any potential consensus about truth (and indeed the search for truth) is coerced by aesthetics - style, not content - and a constant re-digitalisation of reality. Norris persuasively confronted this for him 'deeply untruthful' understanding of truth, as

14.Jameson $(1992,2002)$.

15.See Norris $(1993,1997,1998)$.

16.This is a slightly embarrassing note, as the author wrote two dissertations in philosophy and theology in that very confusing period of the 1990s, in which the word 'postmodern' appears in its titles.

17.Norris (1998:164-180). encountered in the works of possibly Lyotard's most dedicated and fiercest disciple, Jean Baudrillard.

Baudrillard - this is the same Baudrillard who wrote a work ${ }^{18}$ titled Forget Foucault, urging us to forget precisely the one 20th century thinker who always insisted that we should not forget anything, however apparently insignificant - declared that reality after modernity (or rather after Lyotard's version of modernity) is not merely a world of images, but already imitations of images. Baudrillard stated rather bluntly: 'It seems that the majority of people still do not recognize that we have moved into an epoch where truth is wholly the product of images and consensus-values. ${ }^{\prime 19}$ Truth is thus only an effect, a product of intersubjective accord, in an image-replicating and image-imitating world. Obviously, Norris radically contests this notion, as an indicator of exactly how impoverished philosophy has become, how far philosophy has taken leave of its timeworn and indeed ancient sobriety - and how this aesthetic game of innuendo, with the corresponding loss of methodological meticulousness and grounded conceptual analyses, holds fatal consequences for Western selfunderstanding as such.

Both Jameson's and Norris' critiques of the expressed postmodern (that is to say, the post-Lyotard trajectory) resonate inadvertently with the delicate critique of both modernity and postmodernity of Jürgen Habermas, as articulated in his celebrated work, Der philosophische Diskurs der Moderne. In this illustrious work, Habermas resists what he perceives as the radicality of the dislodgment of philosophy in French post-structuralism, notably in the post-Lyotard tradition, although Derrida and Foucault are in his polemic fine hairs of the scope as well.

Habermas repeatedly asks whether these 'postmodern' thinkers appreciate the potentially fatal implications of their radicalisation of Lyotard's cultural analysis. The typical contemporary instruction that philosophy should get rid of its orthodox problem-solving character and obligatory social anxiety and instead become a genre of literary criticism, thus rather occupied with stylistic and aesthetic deliberations than a pathological critique of culture, eventually becoming nothing but a playful aesthetics itself, points for Habermas ${ }^{20}$ to a catastrophic lack of acumen in the outcome of this philosophical dislocation, namely the 'impossibility to express anything significant over the lived lives of individuals'.

Habermas is convinced that the most crucial and essential of all possible philosophical status- or reputation claims have been conceded in the post-Lyotard development in philosophy, to the point of a grotesque alienation from itself. Philosophy is no longer identifiable as philosophy. The challenge, for Habermas, is to stay connected to and engaged in Enlightenment rationality's socio-historical rootedness 18.Baudrillard (2007).

19.Baudrillard, cited in Norris (1993:169)

20.Habermas [1987:294, 408 (footnote 28)] 
and to stay critically interested and involved in concepts such as truth, beauty and justice, without negating the knowing subject's historical and social actuality.

If we have to take leave of modernity, it should be a selective departure of some elements in modernism and not an in toto exodus.

\section{September 2001 and the onset of systematic terror in the West}

Habermas' challenge to philosophy to return to its characteristic ardour for truth and epistemological sobriety was brought to a climax almost 15 years after he postulated his premonitions in Der philosophische Diskurs der Moderne, on a brisk autumn morning in New York City and Arlington, Virginia. On 11 September 2001, the West changed irrevocably and irreversibly. There was an implosion in more than one sense on that fateful day: not only was there physical disintegration - there was a metaphysical collapse, beyond anything the West has ever known, equal to the metaphysical and indeed psychological effect of two brutal world wars in the first half of the previous century. On 9/11, there was an abrupt annihilation of concepts the West was convinced and has understood for a long time, including its understanding of international borders, peace, security, justice and conventions. Not only did the world change on that pitiless Tuesday but also the West's concept of what was conceivable to be antagonised changed within a few hours. There has been since the two world wars of the 20th century no more dramatic point of reference to the vulnerability and exposure of the modern world, how effectively this sophisticated modern world could be brought to its knees by enantiodromia, its own modern tools and instruments, as was on that day.

Only a few weeks after the attacks on the World Trade Centre, Pentagon and US Airspace, a debate took place from the highest stories of a skyscraper looking down on Ground Zero - that sorrowful place where the twin towers once stood, flattened to the ground, with zero left to offer or to promise. Giovanna Borradorri (2003) succeeded in liaising with Habermas and Derrida, coordinating a debate between the two greatest living philosophers in the West at the time. The two thinkers realised the importance of the debate, however far apart they were intellectually and socially. They set their profound differences aside and deliberated for hours, pondering the question of the possibility of justice in what has become a world without justice. Surprisingly enough, the two philosophers found each other over numerous vital issues, the first of which was that philosophy has a deep accountability towards society. Philosophy must reflect and be more than merely self-reflective. Philosophy must occupy and be more than merely self-occupied. Therefore the concept of justice must be dramatically revisited and overhauled, closely connected to the question of injustice, of which terror is the ultimate manifestation. Both philosophers concurred that social terror has within weeks become the most prominent social marker of the 21st century, as was colonialism in the 19th century and totalitarianism in the 20th century. Sadly, their intuition was proved correct, as imprinted on the Western mind ever since - Madrid 2004, Stockholm 2010, Boston 2013, Paris 2015, Brussels 2016, Berlin 2016, Manchester 2017, London 2017 and Barcelona 2017, being the most prominent cases in point.

However, both thinkers were wary and circumspect: the concept terrorism is a dubious one and should be treated with caution, precisely because the concept is consistently employed from both sides of a vicious spectrum.

The most surprising element in this discussion was, against this background, that both thinkers were willing to present concrete proposals, in terms of which the rhetorical, political and social polarisation between good and evil encapsulated in the concept terror could be transcended. Neither Derrida nor Habermas thus hesitated to speak frankly about the reality of terror, injustice and the onset of what they subliminally expected to become the phenomenon of systematic terror in the West.

Courageous as both philosophers were to address these issues so quickly after $9 / 11$, the impression that their discussion was dismal and without soul is justified. Both thinkers left the impression that they were deeply embarrassed, not at all prepared to talk about justice in a 'postmodern world'. Yet both made it clear that the developments in philosophy over the past four decades, but the preceding 15 years, in particular, problematise efforts to speak frankly, in terms of parrhesia, about justice. Perhaps, one could reservedly say, the philosophical value of 11 September 2001 is that this event indicates precisely how displaced and dislodged Western philosophy has become - and how detached she has become from herself.

\section{The 'new wizards of $\mathrm{Oz}^{\text {' }}$}

The reaction of Baudrillard, the pivotal and most radical thinker in the post-Lyotard development in contemporary philosophy, on the events of 11 September 2001 indicates just how far philosophy has moved away from philosophy in recent times. Baudrillard's work was in the mid-1990s already widely acknowledged as 'fresh' and 'provocative'. One could rightly be unsure of the accuracy of either, but what is nevertheless true is that the more moderate tones in Baudrillard's work did find its way into the new labyrinths of the philosophy of technology, which could be considered to be the most promising and consequential of the more recent philosophical discipline-developments since the demise of post-structuralism. In the context of philosophy of technology, the work of Bernard Stiegler should be held in the highest esteem, and it is crucial that contemporary philosophers in this promising field be firmly distinguished from fundamentally unphilosophical writers such as Baudrillard, Paul Virilio and Slavoj Zizek, who indeed summon technological concerns in their writings - the three writers the author have come to know as the 'new wizards of $\mathrm{Oz}^{\prime}$ : 'wizards', because their writings involve more wizardry than philosophy. 
Baudrillard's reply to the terror of $9 / 11$ was completely consistent with what he already pronounced in his earlier works such as Seduction ${ }^{21}$ and Simulacra and simulation, ${ }^{22}$ namely that 'there is no real world', only a world of imitations, where images mirror images, where nothing is ever new or authentic. Baudrillard isolates early modernity as the period between the Italian Renaissance and the Industrial Revolution, modernity as the period that advances from the Industrial Revolution and, in line with Lyotard, postmodernity as the period associated with the ascent of mass-media and the centralisation of the image. He describes himself as the protagonist of the image and the one thinker who would employ Lyotard's futuristic analysis in its logical consequences, whatever the cost..$^{23}$

His interpretation of the significance of $9 / 11$ refers back to another of his earlier idiosyncratic analyses, namely of the Gulf War of 1991, on which he wrote a book titled The Gulf War did not take place. ${ }^{24}$ Baudrillard is completely serious when he stated that the Gulf War did not take place: to begin with, 'war is not warring anymore'.

War is not, as it was in the premodern, early-modern and modern periods, the result of unsolved political disputes eventualised in visceral violence, with the realistic prospect of reinstated peace (ius in bellum). The Cold War MUDprinciple (Mutually Assured Destruction) took war away from the trenches of Delville Wood and the reality of physical Zerstörung - and funnelled it to domains of virtual reality. War is now a programmed operation executed based on preexisting algorithms, thus a war of software. The UN troops in Iraq, for example, did not react on real capabilities of the Iraqi army, but executed a military operation which has been developed per algorithm based on probability considerations.

In other words, the Gulf War was a war of 'information images', CNN newsreels and live video feeds of missile trajectories, as such merely another media phenomenon, just more images. The UN troops did not engage in combat in the conventional and traditional sense, did not answer fire with fire, but engaged in combat against radar signals, GPS coordinates, satellite pictures and infrared images. These are not front lines - just signs, numbers and images. The UN troops and pilots engaged in a virtual war in 1991, however with live ammunition; missiles were placed on the fine hairs, not of a gun, but on a radar screen; using key phrases as 'cargo delivery', 'instrument employment' and 'undesignated objectives'. The Gulf War is thus according to Baudrillard the perfect example of the way the image - as Lyotard, just more than a decade before predicted it would - and the layering of images replaced 'the real'.

Of course, Baudrillard would acknowledge that behind the image are living (and dying and dead) women and children

21. Baudrillard (1990).

22.Baudrillard (1995b).

23.Baudrillard (1995b:33)

24.Baudrillard (1995a) (and soldiers, still) - but this is not the issue any longer. The issue is the image. The image is the issue.

The names of the dead, the nature of their death, are not relevant. 'The real is not real any longer', to quote Baudrillard's celebrated dictum. The real is the image, and the real act is the act of perception. Who would know if the war really took place and perhaps not a twisted Hollywood production? Nobody would know, and it is impossible to say. Did the Gulf War take place? Also, if it did or did not, who cares?

Crucial for the argument is to concede Baudrillard's seductive style and beautiful prose. He truly is an astonishing writer. He is mesmerising - and precisely for that reason a deeply disturbing thinker. He writes about the simulacra in the vernacular of digital philosophy - and not in the language of life, which is in war the language of smoke, fire and cracked open skulls. There is no difference between Baudrillard in his comfortable study and the technical pilot who delivers a deadly missile per software and infrared equipment: both are busy with a deadly game. The events in Iraq in 1991 thus has as little in common with war as internet porno has with sex. War and terror, consequentially, are phenomena which can now only be investigated aesthetically. The tragedy, the enormous loss of life and the profoundly human inquiries to the cause of such brutality do not impress him. Not even once does Baudrillard address the justice, or lack thereof, within this context. The whole and complete truth of blood and trauma degenerates on the strength of his ruthless abstraction. Baudrillard is not able to smell blood.

Surely the messenger should not carry the burden of the message. Baudrillard's point is that if you do not smell blood, you do not smell blood, distressing as it may be. His point is precisely that it has become impossible to smell blood. However, is the authentic philosophical question not that somebody, somewhere is still smelling blood? Moreover, as long as the smell of blood is part of at least one lived life, the smell of blood must be taken seriously by philosophers and cannot be deemed obsolete. If Baudrillard's plush prose about really nothing is an indication of how impoverished we have become philosophically, should we not inquire into how abundantly prolific philosophy once was conceptually, and how disciplined philosophy once was - and how utterly insolvent we have become intellectually since?

The theoretical foundations of Baudrillard's abstracting perspective were postulated more thoroughly in a somewhat later work, Simulacra and simulation. ${ }^{25}$ Again we deal with a dense and sophisticated text. It is precisely the seductive prosaic quality of the text that renders it horrifying. Baudrillard argues that constructions of reality today, in the 21st century, beyond anything ever before, are based on what he calls 'hyper myths'. 'Hyper myths' are real yet have no connection to reality. The fine line between concept and 25.Baudrillard (1995b). 
reality, the signifier and the signified, supernaturally implodes into the concept itself and all that remains is what he (1995b) consequentially calls the 'hyperreal':

$[N]$ o more mirror of being and appearances, of the real and its concept ... No more imaginary coextensivity: its genetic miniaturization is the dimension of simulation. The real is produced from miniaturized cells, matrices, and memory banks and models of control, and it can be reproduced an indefinite number of times from these. It no longer needs to be rational because it no longer measures itself against either an ideal or negative instance. It is no longer anything but operational. In fact, it is no longer really the real, because no imaginary envelops it anymore. It is a hyperreal, produced from a radiating synthesis of combinatory models in a hyperspace without atmosphere. (p. 2, [author's own italics])

The 'hyperreal' is inevitably directed towards confusion, disorientation and apathy, as he (1995b) says:

The territory no longer precedes the map, nor does it survive it. It is nevertheless the map that precedes the territory - precession of the simulacra - that engenders the territory, and if one must return to the fable, today it is the territory whose shreds slowly rot across the extent of the map. It is the real, and not the map, whose vestiges persist here and there in the deserts that are no longer those of the Empire, but ours: The desert of the real itself. (p. 1)

Precisely the same self-destructive logic repeats itself eventually in Baudrillard's notorious yet extremely fashionable commentary on $9 / 11$, The spirit of terrorism. ${ }^{26}$ Again Baudrillard finds no use for notions of reality, truth and justice in this context, as he found no use for it in the context of contemporary warfare. He intentionally sidesteps the real fate of the thousands of victims in the Twin Towers, Pentagon and hijacked passenger jets. $\mathrm{He}$ is far more interested in the 'aesthetics' and symbolism of the attacks, the images mirroring the events and the operational quality of the media coverage on that particular day. In cold blood, Baudrillard focuses on the attacks as expressions of a 'sacrifice symbolism', wherein the hijacker is depicted as the perfect symbol of an ancient sacrifice which, combined with Western high-technological equipment and capabilities, did not have an offensive objective as such, but rather an unveiling one: the intention of the attacks was to unmask Western civilisation as an 'aesthetic event'.

The events of 11 September 2001 should thus be interpreted aesthetically, as an episode in which an ultra-sophisticated West was brought down to its knees by non-Westerners, yet through enantiodromia, that is, precisely by means of Western technologies - and of course, Western images. The impact of the attacks is not to be measured in the number of fatalities, but in the media coverage, the spectacle, the image, according to Baudrillard, which the attackers certainly bargained on. It is futile to look for a judgement, a sympathetic assessment, a moral choice, in this terrifying text: the terrorist, that is, the one that terrorises, is presented as an erudite analyst of Western culture, as an aesthetic figure - whilst not even once 26. Baudrillard (2003). issues regarding truth and justice are considered. At the end of this harrowing work, the author once again, as was the case in his review of the Gulf War, denies the 'reality' and 'actuality' of the event, whilst he once again envelopes it in the 'pseudo-quality' of any event that is covered by mass media; once again a case of the image consuming the event.

Of course, Baudrillard would acknowledge that 'terrorism' is immoral, but only in so far as society itself is immoral. In other words: 'terrorism' is nothing but an authentic answer to questions produced by Western society itself. Baudrillard describes a system struggling to universalise itself - and failing itself. What the West thus calls 'terrorism' is nothing but a natural virus, a particular inescapable resistance against a universalising credo.

Globalisation wrestles with itself after it was punched out in New York in a 'symbolically perfect' way.

Baudrillard notably does not consider the attacks as 'perfect', rather the effect of it: the implosion of those two massive skyscrapers was 'perfect'. Indeed, Baudrillard could not ask for a more powerful symbol, because that is what he was looking for, the 'West's suicide'. Seldom, if ever, was poetry so 'powerful, so aesthetic, so bound to truth', as he (2003) stated:

Imagine they had not collapsed ... the effect would not have been the same at all. The fragility of global power would not have been so strikingly proven. Seeing them collapse themselves as if by implosion, one had the impression that they were committing suicide ... Their symbolic collapse brought about their physical collapse, not the other way around ... Their nerves of steel cracked. They collapsed vertically, drained of their strength. (p. xx)

Is this what has become of philosophy in the 21st century? Is this all that remains philosophically, merely describing a universe where nothing is black or white or safe or logical, that Baudrillian universe where nothing is true and nothing unjust, that spectral, confusing, insane 'desert of the real'? This is Baudrillard's symbolic universe, where reality can only be weighed ideologically and aesthetically: women pulling out their hair, wholly overcome by the monstrosity of the real event, 'real' because falling bodies and the smell of blood and burning human flesh are real, appeared to Baudrillard as unaesthetic and obnoxious. In so far as he has any attachment to reality, Baudrillard preferred to focus on the end of the two architectural Janus twins he despised so intensely.

Perhaps not all is lost. The fervent reaction from the international community - and later from within both Democratic and Republican communities in the US itself - against the War in Iraq, with regard to fraudulent misrepresentation, political opportunism and the manipulation of information, indicates that people are still able to think beyond images and to recognise the lived life for what it is; still able to scrap Jameson's postMarxist camouflage paint. If Baudrillard's postulations were correct, it would not have been possible to identify 
misrepresentations and the manipulation of information regarding, for example, weapons of mass destruction.

The fact that people were still able to see 'through the image', beyond established political frameworks, questions the notion that the image is her own pure simulacrum. Or was this only an incidental glimmering of light of sobriety in Baudrillard's 'desert of the real'?

Two skilled European critics of culture, at the time still relatively unknown yet since quite famous, Paul Virilio and Slavoj Zizek, trail Baudrillard's 'aesthetic' assessment of 9/11 quite devotedly: the relatively subversive publisher Verso published together Baudrillard's The spirit of terrorism, Virilio's Ground zero ${ }^{27}$ and Zizek's Welcome to the desert of the real: Five essays on September 11 and related dates, ${ }^{28}$ the last an explicit reference to Baudrillard's hailing of the 'desert of the real'. Virilio is convinced that what is called 'progress' in terms of the spirit of the Enlightenment, actually points towards technological progress that progressively marginalises humanity, as manifested in the intimate relationship between commodities, art and the media in a contemporary consumerist culture. As far as Virilio is concerned, the notion of 'progress" is an utterly bleak one, referring not to a humanity that bravely steps into the future, but a humanity to be destroyed by its cultural artefacts, of which technological products are the most assertive.

Not less clinical than Baudrillard in his most ruthless streaks of apathy, the concept terror is presented by Virilio as an occurrence for which the West itself is to answer for - and not the so-called 'terrorists'. Al-Qaeda is again depicted as an agent of nostalgia, symbolic of the regressive nature of globalisation. Again, not even once the act of terror is addressed in terms of considerations of justice: actually, the acts of terror on $9 / 11$ and the many deeds of trepidation after that should remind 'us Westerners' how much 'we' have transgressed and how much 'we' have destroyed. The terror attacks were, in this sense, a symbolic, introspective gift. AlQaeda has done 'us Westerners' a massive favour by forcing us to readdress 'our' notion of 'progress'. May 'we', the 'Westerners', ask the same question to the 'other side'?

Is not the truth far simpler and discursively altogether clearer, namely that the acts committed on 9/11 were sly, vicious and cowardly, directed against innocent people who drank their morning coffee and went to work? May one still postulate this conviction so directly? Alternatively, are all that remain these echoes of the decline of the Western self-understanding and the glorification of the (indeed) terrorist as 'an aesthetic agent for introspection', a kind of noble agent provocateur? May one still be convinced that philosophy, as a truly technical and scientific discipline, has more to offer than what Baudrillard and Virilio offered - especially in the light of the many (and not less callous) attacks on the West post-9/11?

27.Virilio (2002).

28.Zizek (2002)
Although Zizek's text was philosophically more evenhanded and less harrowing than that of Virilio, he nevertheless stayed theoretically close to the two other wizards. The premise in Welcome to the desert of the real is that the single biggest mistake made by the US in the afterglow of $9 / 11$ was to consider itself a 'victim': rather than using the attacks as an incentive to rethink its international policies, the US answered fire with fire - a strategy, as we have seen in Baudrillard's work, considered as counterproductive and even as meaningless in the image-fixating 21st century. The only way the US could prevent a similar attack on home soil is to prevent the 'repetition of the image' - by establishing conditions that would render such an attack as unnecessary elsewhere in the world. Now, for those still under the spell of 'postmodernity' this suggestion may carry substance, but it should rather be considered a baffling naïve notion.

Zizek was indeed more nuanced about the naked Schadenfreude regarding American trauma on 9/11, and he certainly did not participate in the postulation of the suicidal act as a 'symbolic' and an 'aesthetic' sacrifice. He also commentated in a balanced way on the nature of Western vis$\grave{a}$-vis Islamic fundamentalism. However, in the end there was also in Zizek's case an unwillingness to consider terror on the West conceptually in terms of justice - in all his originality, Zizek too hesitated before the truth and reality of blood and terror.

\section{Sensus communis: Medieval philosophy, common sense and community sense}

The author has recently published a monograph on French philosopher Michel Foucault (1926-1984), focusing on his infamous journalistic expedition to Iran during the unfolding of the revolution in the country in the second half of $1978 .{ }^{29}$ In the work Foucault's Iran writing ${ }^{30}$ from the time are placed in idea-historical perspective, indicating implications of his unique interpretation of Otherness in the context of Islamofascism in the 21st century. It is argued that Foucault, however hostile the (especially Marxist) receptions of those writings were at the time, presented an astonishing insight into a radically new political constellation towards the end of the 20th century, consisting of concepts such as power, politics, political spirituality and religion - concepts in modernism considered to be totally incommensurable. Foucault was sensitive for an Islamic alternative to Eurocentric political paradigms, which was at the same time deemed in Europe to be regressive and a free-fall back to a pre-modern 'barbarism'. He was seriously interested in religion as a political force and the 'political spirituality' that ignited the revolution. Foucault, with forensic precision, detailed the events in Iran as a unique political discourse, which resisted modern regimes of observation, control, normalisation and examination.

29.Beukes (2020b; see $2009 a-b)$.

30.Foucault (1978a-h). 
In a time where it has become urgent to reinterpret the complex worlds of both Sunni and Shia Islam, Foucault, by focusing on an analysis of that unique political spirituality, presented parameters to initiate this reinterpretation, including the idiosyncrasies of power, spirituality and obedience in Islam. Foucault did not present prose or literary theory from Iran: he presented analyses - and the author, if only out of respect for the quality of those analyses reanalysed his writings, by cautiously, in an almost scholastic word-by-word exegesis, presenting hypothetical premises for investigation as well as hermeneutic questions (the sort of questions Medieval philosophers referred to as quaestiones). In the end, conclusions are weighed up to the hypothetical premises, giving Foucault the benefit of the doubt if and where necessary.

Again: is this way of doing philosophy in the continental tradition still sustainable if not respectable in philosophy? Or does one now have to summarily choose between the postLyotard version of continental philosophy and 'analytical philosophy', per Quine and Wittgenstein, who present a completely different world view than that in continental philosophy? And, given this other 'English' choice's philosophical and indeed its indexed 'otherness', must one now commit to literary theory in order not to become an analytic philosopher, so that one can specialise only in ambiguities, language-games and post-structuralist enigmas, with philosophy having become nothing more than a code breaker, a chic Enigma machine? In other words: can one still be a continental philosopher and yet still be seriously analytical in one's approach and methodology, without risking being labelled as 'non-continental' or 'analytical'?

It should be clear by now that the author is acutely resisting these developments in (indeed continental, notably French) philosophy, in terms of which this Foucaultian student of the Western history of ideas is taken where he pertinently does not want to be in Baudrillard's desert of the real. Of course, there are many other philosophers in the continental tradition with the same conviction - yet we have become by far the minority. One has to really explore the contemporary rubric of philosophy to find exponents of the non-Baudrillian type: thinkers like Bernard Stiegler, possibly the greatest philosopher alive today, working (although not exclusively) in the youngest sub-discipline in philosophy, that of Philosophy of Technology, which is the most promising development in philosophy since the advent of Philosophical Hermeneutics many decades ago. Or perhaps Giorgio Agamben, who, in his delicate bring-back-to-life reinterpretations of the Western history of ideas as manifested both in philosophy and theology, has presented an exquisite alternative to Baudrillianism over the past two decades? Of course, there are others as well. Fact is, where thinkers like Stiegler and Agamben represented the rule and not the exception in continental philosophy until a few decades ago, they now are exceptions to the Baudrillian-Virilian-Zizekian rule of a mere image-driven and code-breaking philosophy. ${ }^{31}$ Thinkers like 31.See, for example, Agamben (1993; 2012 \& 2013).
Stiegler and Agamben specify that philosophy, both as an idea-historical and a scientific, technical discipline, has more to offer than what is currently being offered by mainstream 'pop' philosophy and what is currently being manifested in academic and public life as 'philosophy'.

Again, the prerequisite to take philosophy back to her roots is the presence or desire to bring to expression the metaphysical best in the discipline, yet dialectically to be loved and transformed by philosophy, so that she brings to expression the metaphysical best in her philosophers. Without this love and desire for wisdom and this wisdom's reciprocal love, philosophy is never possible. Then it becomes nothing but techne, a mere mechanism for knowledge, which will never have more to offer than questionable claims to 'applicability' and beastly instrumentalism. However, how does philosophy become wijsbegeerte again? How can philosophy's ancient ardour for conceptual sobriety and levelheadedness be rehabilitated in the 21st century? Should one not have to return to an understanding of philosophy which employed truth concepts which were recognised as such, as truth instead of innuendo? Is the problem of truth, as Hans-Georg Gadamer so convincingly argued in Wahrheit und Methode, not in the end genuinely hermeneutical? ${ }^{32}$

If we take as our premise Gadamer's famous statement Being that can be understood is language - should one not go even further and postulate that the problem of truth is in the end logical-hermeneutical? If we take Gadamer's persistent emphasis on language, precisely as the faculty that understands Being, manifesting itself as a form of collective or communal knowledge, should we not deduce that principles of language and logic, which lend itself to communication or 'communicative action', are to be considered the most paramount in philosophy? Such a paramount principle of language and logic is sensus communis, a term highlighted by the early modern Jesuit Vico (16881744), in his 18th-century endeavours to find principles of language and logic which were at heart both comprehensible and communicative in an unmediated sense.

We inherit the notion of sensus communis from the Medieval philosophers' - especially from the late-Medieval Franciscan tradition - consistent regard for it, as eventually developed by the English empiricists during the 18th century. These empiricists understood sensus communis firstly as common sense and secondly as community sense, which in any case scenario concerning the truth, beauty or justice of a particular presentation, acts as the principle by which a rational understanding of that particular presentation could be unproblematically communicated in a particular community. Of course, that does not imply that such a particular presentation concerning truth, beauty or justice always has to be unproblematically communicative in a particular community, or in any other community, for that matter. Moreover, it does not imply that such a presentation always is readily communicative. Rather, sensus communis as common sense and 32.Gadamer (1979:19). 
community sense implies that there are events, or there could be events, that are so pure, clear and flawless in its selfpresentation, that they unmistakably are what they are, be it truth, beauty or justice - or unmistakably are it not, as understood from within the localised particularity of a specific historical, linguistic and geographic community.

These sorts of events are thus not categorically true, but uncategorically true: they are not mediated by one or more categories, neither in the Aristotelian nor in any other sense. These sorts of events overcome the subject, so to speak. They are the significant exceptions in an indeed mediated world, where the mediation of things by many things, images included, is the rule. Yet 'significance' is significant precisely because it is not the rule, not ready-made in the world, but always to be found in the 'world behind eyes'. Sometimes, however seldom and exceptional, the subject can be overcome by that which is rationally true, good or justified.

A logical-hermeneutical locus would on the basis of sensus communis as common sense and community sense, involve a simple syllogistic proposition:

1. reality as understood by particular and localised subjects is thoroughly mediated;

2. there are nevertheless events that overcome particular and localised subjects in an unmediated sense;

3. therefore reality cannot be described as truly mediated.

In other words, the acting and knowing subject knows reality in terms of multiple categories of the mediation of reality. Yet the same subject can be overcome by events, which, given this subject's localised and particularised historicity, will be unproblematically recognisable as truth, good, beauty or justice - or not, however exceptional that may be. ${ }^{33}$ Therefore the subject is bound to more than categories of mediation.

This is a logical standpoint, once again referable by syllogism. The proposition 'all statements are false' can only be a comprehensible statement if it is made from a position beyond the logical-syllogistic structure of the proposition. The proposition 'all statements are false' presupposes namely a unique position where it becomes possible that at least one statement is not false, namely the position in terms of which the statement 'all statements are false' is a true statement. The fate of the proposition 'all statements are false' stands and falls with this logical allowance.

The proposition 'everything is mediated' can similarly not be logically accepted if it is itself a mediated statement.

You cannot be judge and advocate in the same case, and you cannot plea and judge in the same case, can you? The proposition 'everything is mediated' presupposes once again a position - even if it is an extremely enigmatic position in which it becomes possible to make an unmediated,

33 Although there is no need to postulate a theore.................................... of sensus communis beyond a logical-hermeneutical position, one could refer to quite a number of eminent examples of it in contemporary, non-Lyotardian quite a number of eminent examples of it in contemporary, non-Lyotardian
philosophy, as in Foucault's (e.g., 1978a, 1978b) notion of 'political spirituality', or Derrida's well-known notion of 'the Event'. recognisable, comprehensible, communicative and transparent statement, namely that 'everything is mediated'. The destiny of the statement 'everything is mediated' is thus determined by the enigma of the unmediated and not the inevitability or universal necessity of the mediated.

The roots of this grammatological consequence - that there must be, however enigmatic, an unmediated reality in a world of constant mediation - if of course nowhere evident in the modern realm and must be traced back to the premodern, that epoch which is characterised with so much cultural bias and historical prejudice as 'dark', if not ignorant of the essence of things. The author has recently published an extensive introduction to Medieval philosophy in the ideahistorical genre, consisting of 150 chapters in which 145 Medieval philosophers are presented based on inter alia their sense of sensus communis. ${ }^{34}$ A conscious effort was made to isolate the elements in this vast corpus that point towards sensus communis notions, such as clarity, comprehensibility and transparency in the localised community. The many Medieval philosophers, systematically discussed on the basis of fresh translations of their primary texts from Arabic, Latin, Hebrew and Greek, indicate that there was a time - and not Baudrillard's 'imagined time' - where an unproblematic validity and foundational bases for the explanation of reality and contents of concepts, such as truth, the good, beauty and justice, were at a time accepted as 'common sense'. This longing for conceptual clarity and communal transparency was thus established a long time before Vico and his development of sensus communis in Jesuit pedagogics: indeed, throughout the millennium-long epoch we know as the 'Middle Ages'.

Of course, the notions of common sense and community sense embedded in sensus communis seem today such disputable and even dubious contentions that few respectable continental intellectuals would consider reappraising them especially those under the spell of postmodernism, for whom someone like Baudrillard speaks the truth and the truth only. It could be contended, however, that the willingness to engage the forgotten or lost moments in the history of ideas, following Hans Blumenberg, Walter Benjamin and again Foucault in this regard, and despite the non-progressive and non-teleological nature of such an engagement, should be the hallmark of authentic intellectual commitment in the 21st century.

Gadamer accentuated ${ }^{35}$ that Vico should be interpreted outside the Cartesian tradition. Sensus communis was, for Vico, not based on a specific mathematical, rational ideal (such as in Hobbes' Leviathan or in Descartes' Meditationes), but on a discursive platform where practical, communal considerations could be expressed unproblematically, and choices be made based on a high level of certainty (verum certum). Common sense and communal considerations were judgements, immediate and certain, which could be unproblematically 34.Beukes (2020a). 35.Gadamer (1979:20). 
communicated and comprehended. What Vico, as a professor in logic, added to verum certum was the classical rhetorical idea of eu legein - to speak the truth well and meaningful, in correspondence with the old Aristotelian idea of parrhesia, to speak frank and fearless. What the combination of verum certum, eu legein and parrhesia offered was the possibility to say 'good things', always speaking the truth - and to say 'good things in a good way', always speaking the truth meaningfully and frankly.

In the author's endeavours to reinterpret sensus communis in (and for) the 21st century, the implementation of verum certum, eu legein and parrhesia indicates that there are things in this world that can be spoken of meaningfully, unproblematically and with certainty. Of course, this notion has been demolished by the later modern project, considered as naïve and even primitive; a regression to a time before the Aufklärung and emancipation of humanity, who seemingly did not need conceptual clarity and communicative action any longer.

The crucial question is: if this emancipation itself is failing, and the modern project is in its extreme consequences (as in Baudrillard's thought) indeed catastrophically rushing towards the abyss - what alternatives to this declining sense of freedom can be presented? One such alternative, one could argue, is the reappraisal of the premodern, where important things were indeed deemed verum certum.

That is why Gadamer, in his exposition of sensus communis, elaborated $^{36}$ on the Aristotelian-scholastic backgrounds of this profoundly Medieval conviction: this tradition set itself polemically up against the type of metaphysics which was dissolved in scepticism, in terms of which nothing could be known definitively - and never considered that lack of knowledge' to be a fundamental problem of philosophy. This tradition thus proposed an anti-sceptical approach of sober judgement, der gesunde Menschenverstand, le bon sens, sensus communis. The Aristotelian-scholastic tradition's contribution to the development of the notion of sensus communis, can indeed hardly be exaggerated: On the one hand, on the basis of this tradition's characteristic emphasis on the senses' ability to produce knowledge, within the trusted frames of the faculty of the active intellect, its opposition to the many excesses in the name of speculative philosophy in the Middle Ages; on the other hand, the accentuation of the profound relationship between sensus communis and communal life. Of this relation, Gadamer (1979) said that:

$[P]$ hilosophy of clear and sober judgement not only acted as a remedy for a moonstruck metaphysics but provided the basis on which a moral philosophy, which took the notions of 'the good' and 'justice' seriously, could be consistently developed in the social realm. (p. 25) ${ }^{37}$

In fact, there would have been no possibility for the creation, preservation and development of a Western Self had it not

36.Gadamer (1979:25)

37.Gadamer (1979:25) been for Medieval monastery life and the sensus communis philosophy that was brought forth from its darkest and most hidden corners: since Boethius in the sixth century presented a translation and commentary of Aristotle's De Interpretatione and Categoriae to the early Benedictines, the notion of sensus communis resonated with the essence of Benedictus of Nursia's 73 rules for the order: Recognize truth, defend truth and live truthfully in community with others.

The author readily anticipates a rather brusque reaction against this rehabilitating reception and presentation of Medieval philosophy: the attempt to reappraise Medieval thought within the context of sensus communis to combat the contemporary dislocation of philosophy. There is no doubt that a definite notion of continuity is hereby presented. It is possible that a new individualising myth is at work here, explicitly so in the repetition of an 'older image', however still 'an image'. Perhaps the intense love for Medieval monks and nuns in the author's work, bordering on the erotic, indicates a more profound desire, namely for a united, fixed, centralised Self in that sense, indicating a free-fall back into high modernity. Of course, the interpretation of sensus communis reveals a profound indebtedness to deep or immersed structures (meaning, significance, content and the signified) as opposed to superficial structures (appearances, external forms and the self-imploding signifier). Quite evidently, sensus communis denies the validity of Baudrillard's 'hyperreal' and is directly opposed to Baudrillard's and his contemporaries' conviction that nothing is real in the unmediated sense, or real beyond appearances. At first blush, it may seem that, although the above argument is non-teleological and even anti-teleological, the interpretation of sensus communis, in the end, betrays a historical linearity. It is also true that the metanarratives of succession and the authority of tradition are considered to be as relevant today as it had been in the fourteenth century: in fact, the author stresses that the survival of the West's sense of Self is utterly dependent on it. This is all correct, and the author has no qualms about these sorts of reactions.

However, what else is left when there is nothing left? Is a fusion of traditions, the very old and the somewhat recent, not a plausible avenue out of the impasse created by the contemporary dislocation of philosophy? On who else can we call if it becomes evident that the critique of modernity is failing both modernity and its supposed successor? What else than the reconsideration of the marginalised if not forgotten moments in the history of ideas left when philosophy occupies itself merely with the repetition of appearances and an offhand sublimation of brutality? How else can we speak frankly of justice, so that others can understand us and differ from us? What else other than an intimate discourse with tradition is left in the 21st-century era of social terror - the era in which it has become undeniable that we will always have too little in hand to declare the relevant tradition obsolete?

This article is not an argument for a linear regression into the Middle Ages; instead for a cyclical return to what was essential to philosophy for more than a millennium, by raising the possibility of the presentation of first-order 
judgements via sensus communis in a new pursuit for wijsbegeerte. This wijsgerig pursuit requires that one be able to take distance from oneself, to draw back, to learn to be silent so that one can speak, and to learn to speak so that one can learn to be quiet, in order to learn once again to live with Others, as Others with us. ${ }^{38}$ This pursuit demands negation, Adorno's ${ }^{39}$ bestimmte Negation, the ability to say no to the prior synthesis. As the 'last Medieval philosopher', Nicholas of Cusa ${ }^{40}(1401-1464)$, stressed by calling on one of the earliest Medieval philosophers, Pseudo-Dionisius ${ }^{41}$ (ca. 500) to reilluminate decaying metaphysics in post-scholasticism, ${ }^{42}$ should we not call upon our predecessors to rearticulate a contemporary metaphysics? Moreover, duly so in the context of late-modernity's fragmentation of crucial concepts in philosophy, to affirm that our humanity is at its deepest level intertwined with metaphysical inquisition?

Let us now recall the Econian question posed at the beginning: What are the prospects in the 21st century of reorienting Western philosophy from its idea historical sources, which would include its ancient traditions and the Medieval exposition as well as the Renaissance elucidation thereof - as indeed an immunological precaution against the contemporary fragmentation of the relation between Self and Other, identity and non-identity and justice and community? ${ }^{43}$ Are these prospects, if they can somehow be realised, not exemplary guides which will always bring us again to a standstill before the restless spaces between forms and the Abyss, words and the Silence, concepts and the Mystery and the many and the One? Indeed, a new metaphysics may be dawning upon us.

\section{Acknowledgements Competing interests}

The author declared that no competing interests exist.

\section{Author's contributions}

J.B. is the sole author of this article.

\section{Ethical consideration}

This article followed all ethical standards for a research without direct contact with human or animal subjects.

\section{Funding information}

The Department of Philosophy, University of the Free State, funded the page and publication fees of this article.

38.In this regard, Nietzsche (1886) said:

I have learned to keep silent sometimes, and also that one has to learn to talk, to be quiet in the proper way: that a person with backgrounds has to have foregrounds, be it for others, be it for him or herself. For the foregrounds are necessary to recove from oneself and to make it possible for others to live with us (p. 232, [author's translation]).

39.Adorno (1971:101).

40.Beukes (2018b).

41.Beukes (2018a); cf. Goosen (2017:557-591; Perl 2007).

42.Beukes (2020e:1-3).

43.Colish (1999:4).

\section{Data availability statement}

Data sharing is not applicable to this article as no new data were created or analysed in this study.

\section{Disclaimer}

The views and opinions expressed in this article are those of the author and do not necessarily reflect the official policy or position of any affiliated agency of the author.

\section{References}

Adorno, Th.W., 1971, Zur Metakritik der Erkenntnistheorie, Gesammelte Schriften, Frankfurt am Main, Suhrkamp, 9-45.

Agamben, G., 1993, The coming community, transl. M. Hardt, University of Minnesota Press, Minneapolis, MN.

Agamben, G., 2012, The church and the kingdom, transl. L. De la Durantaye, Seagull, London.

Agamben, G., 2013, The highest poverty: Monastic rules and form-of-life, transl. A Kotsko, Stanford University Press, Stanford, CA.

Baudrillard, J., 1990, Seduction, transl. B. Singer, Ctheory Books, Montreal. https://doi. org/10.1007/978-1-349-20638-4

Baudrillard, J., 1995a, The Gulf War did not take place, transl. P. Patton, Indiana University Press, Bloomington, IN.

Baudrillard, J., 1995b, Simulacra and simulation, transl. S.F. Glaser, University of Michigan Press, Ann Arbor, Ml. https://doi.org/10.3998/mpub.9904

Baudrillard, J., 2003, The spirit of terrorism, transl. C. Turner, Verso, London.

Baudrillard, J., 2007, Forget Foucault, transl. N. Dufresne, Semiotext(e), Los Angeles, CA.

Beukes, J., 1996, 'Michel Foucault en die historisering van Anderswees', HTS Teologiese Studies/Theological Studies 52(2-3), 233-251. https://doi.org/10.4102/hts.v52i2/ 3.1496

Beukes, J., 1998, 'Eindigheid, eie opstanding en die politiek van différance', HTS Teologiese Studies/Theological Studies 54(4), 1075-1084. https://doi.org/10. 4102/hts.v53i4.1766

Beukes, J., 2002a, 'Ars erotica en die detrivialisering van die seksuele diskoers: ' $n$ Aantekening by die seksualiteitsanalise van Michel Foucault', HTS Teologiese Studies/Theological Studies 58(1), 283-298. https://doi.org/10.4102/hts.v58i1.541

Beukes, J., 2002b, 'Vanaf laat-strukturalisme na post-strukturalisme: 'n Kontekstualisering van Jean-Francois Lyotard se Discours, Figure', HTS Teologiese Studies/Theological Studies 58(3), 994-1010. https://doi.org/10.4102/hts.v58i3.583

Beukes, J., 2005, 'Terreur, roes en ordes: Die monnik as blywende simbool van erns in die filosofie', HTS Teologiese Studies/Theological Studies 61(4), 1101-1129. https://doi.org/10.4102/hts.v61i4.474

Beukes, J., 2009a, 'Hamartia: Foucault \& Iran 1978-1979 (I Introduction \& texts)', HTS Teologiese Studies/Theological Studies 65(1), Art. \#124, 101-115. https://doi. org/10.4102/hts.v65i1.124

Beukes, J., 2009b, 'Hamartia: Foucault \& Iran 1978-1979 (II Scholarship \& significance)', HTS Teologiese Studies/Theological Studies 65(1), Art. \#125, 116-125. https://doi. org/10.4102/hts.v65i1.125

Beukes, J., 2018a, " $n$ Herlesing van Pseudo-Dionisius se metafisika', HTS Teologiese Studies/Theological Studies 74(4), Art. \#5111, 12186-12190. https://doi.org/ 10.4102/hts.v74i4.5111

Beukes, J., 2018b, 'Dionisiese spore in Kusa se metafisika', HTS Teologiese Studies/ Theological Studies 74(4), Art. \#5112, 12190-12198. https://doi.org/10.4102/hts. v74i4.5112

Beukes, J., 2018c, 'Die Arabiese trajek in die Karolingiese periode in Middeleeuse filosofie', Litnet Akademies 15(3), 502-564.

Beukes, J., 2018d, 'Die Arabiese trajek in die post-Karolingiese periode in Middeleeuse filosofie', Litnet Akademies 15(3), 565-626.

Beukes, J., 2019a, 'Hildegard von Bingen as 'n 12de-eeuse filosoof-teoloog', Litnet Akademies 16(1), 64-102.

Beukes, J., 2019b, 'Policraticus en Metalogicon: 'n Bywerking van die Saresberiensisnavorsing, 2013-2018', Verbum et Ecclesia 40(1), Art. \#1959, 1-14. https://doi. org/10.4102/ve.v40i1.1959

Beukes, J., 2019c, "“Foucault se sodomiet": Damianus se Liber gomorrhianus (1049) heropen', HTS Teologiese Studies/Theological Studies 75(4), Art. \#5216, 1-13. https://doi.org/10.4102/hts.v75i4.5216

Beukes, J., 2019d, 'Héloïse d'Argenteuil se filosofiese uitset', HTS Teologiese Studies/Theological Studies 75(4), Art. \#5281, 1-12. https://doi.org/10.4102/ hts.v75i4.5281

Beukes, J., 2019e, “"Maak die wêreld nie tot bespotting nie”: 'n Herwaardering van die filosofiese aspekte in Mechtild von Magdeburg se Das fließende Licht der Gottheit (1250)', Verbum et Ecclesia 40(1), Art. \#1965, 1-8. https://doi.org/10.4102/ ve.v40i1.1965

Beukes, J., 2019f, 'De potestate regia et papali: ' $n$ "uurglas"-bywerking van die mees onlangse Quidort-navorsing', Litnet Akademies 16(2), 109-168. 
Beukes, J., 2020a, Middeleeuse Filosofie, Volumes I \& II, Akademia, Pretoria.

Beukes, J., 2020b, Foucault in Iran, 1978-1979, AOSIS, Cape Town.

Beukes, J., 2020c, 'Omnium expetendorum prima est sapientia: Hugo van Saint-Viktor (1097-1141) en die probleem van hiperspesialisasie in die eietydse wetenskapsbegrip', Litnet Akademies 17(1), 262-297. https://www.litnet.co.za/ wp-content/uploads/2020/04/LitNet_Akademies_17-1_Beukes_262-297.pdf

Beukes, J., 2020d, 'Die eliminering van die siel in die filosofiese mistiek van die begyn Marguerite Porete (1250-1310)', Litnet Akademies 17 (forthcoming).

Beukes, J., 2020e, 'Die triomf van 'n post-skolastieke mistiek oor skolastieke lojalisme: Gersonius versus Ruusbroec (postuum), 1399', HTS Teologiese Studies/Theological Studies 76(1), Art. \#5672, 1-12. https://doi.org/10.4102/hts.v76i1.5672

Beukes, J., 2020f, "n Nijmegenaar aan die Universiteite van Parys en Heidelberg in die latere Middeleeue: die lewe en werk van Marsilius van Inghen (ca.1340-1396)', Verbum et Ecclesia 41(1), Art. \#2038, 1-11. https://doi.org/10.4102/ve.v41i1.2038

Beukes, J., 2020g, 'The Dominican Robert Kilwardby (ca.1215-1279) as schoolman and ecclesiastical official', Verbum et Ecclesia 41, Art. \#2065 (forthcoming).

Beukes, J., 2020h, 'Intervroulike seksualiteit in die latere Middeleeue: 'n ideëhistoriese oorsig', Verbum et Ecclesia 41, Art. \#2074 (forthcoming).

Beukes, J., 2020i, 'The 50-year jubileum of the Society for the Promotion of Eriugenian Studies in the John Scotus Eriugena (815-877) research, 1970-2020', Verbum et Ecclesia 42 (forthcoming).

Beukes, J., 2020j, "Die "vyf trane" as mistieke uitdrukking in die Dialoë van die Dominikaanse non Katherina van Siena (1347-1380)', Litnet Akademies 18 Dominikaanse
(forthcoming).

Boethius, 1934, De consolatione Philosophiae, Corpus Scriptorum Ecclesiasticorum Latinorum 67, Kommission zur Herausgabe des Corpus der lateinischen Kirchenväter, W. Weinberger (ed.), Österreichische Akademie der Wissenschaft, Kirchenväter, W. Weinberger (ed.), Österreichische Akademie der Wisse
Vienna. For a solid recent English translation, see Watts (transl.) 1998.

Borradori, G., 2003, Philosophy in a time of terror: Dialogues with Jürgen Habermas and Jacques Derrida, University of Chicago Press, Chicago, IL. https://doi. org/10.7208/chicago/9780226066653.001.0001

Cicero, M.T., 1914, De amicitia, IX, Loeb Classical Library, London.

Colish, M.L., 1999, Medieval foundations of the Western intellectual tradition, 400 1400, Yale University Press, New Haven, CT.

D’Argenteuil, H., 1855, 'Epistola II', in J.-P. Migne (ed.), Patrologia Latina, p. 178 viewed 06 January 2020, from http://patristica.net/latina.

De Rijk, L.M., 1977, Middeleeuwse Wijsbegeerte. Traditie en Vernuwing, Assen, Amsterdam.

Eco, U., 1997, The search for the perfect language, transl. J. Fentress, Blackwell, Oxford.

Foucault, M., 1978a, 'The army - When the earth quakes', transl. K. De Bruin \& K. Anderson, in J. Afary \& K. Anderson (eds.), 2005, Foucault and the Irania revolution: Gender and the seductions of Islam, pp. 189-194, University of Chicago Press, Chicago, IL.

Foucault, M., 1978b, 'The Shah is a hundred years behind the times', transl. K. De Bruin \& K. Anderson, in J. Afary \& K. Anderson (eds.), 2005, Foucault and the Iranian revolution: Gender and the seductions of Islam, pp. 194-198, University of Chicago Press, Chicago, IL.

Foucault, M., 1978c, 'Tehran: Faith against the Shah', transl. K. De Bruin \& K. Anderson, in J. Afary \& K. Anderson (eds.), 2005, Foucault and the Iranian revolution Gender and the seductions of Islam, pp. 198-203, University of Chicago Press, Chicago, IL.
Foucault, M., 1978d, 'What are the Iranians dreaming about?', transl. K. De Bruin \& K. Anderson, in J. Afary \& K. Anderson, 2005, Foucault and the Iranian revolution: Gender and the seductions of Islam, pp. 203-209, University of Chicago Press, Gender and th

Foucault, M., 1978e, 'A revolt with bare hands', transl. K. De Bruin \& K. Anderson, in J. Afary \& K. Anderson (eds.), 2005, Foucault and the Iranian revolution: Gender and the seductions of Islam, pp. 210-213, University of Chicago Press, Chicago, IL.

Foucault, M., 1978f, 'The challenge to the opposition', transl. K. De Bruin \& K. Anderson, in J. Afary \& K. Anderson (eds.), 2005, Foucault and the Iranian revolution: Gender and the seductions of Islam, pp. 213-215, University of Chicago Press, Chicago, IL.

Foucault, M., 1978g, 'The revolt in Iran spreads on cassette tapes', transl. K. De Bruin \& K. Anderson, in J. Afary \& K. Anderson (eds.), 2005, Foucault and the Iranian revolution: Gender and the seductions of Islam, pp. 216-220, University of Chicago Press, Chicago, IL.

Foucault, M., 1978h, 'The mythical leader of the Iranian revolt', transl. K. De Bruin \& $\mathrm{K}$. Anderson, in J. Afary \& K. Anderson (eds.), 2005, Foucault and the Iranian revolution: Gender and the seductions of Islam, pp. 220-223, University of Chicago Press, Chicago, IL.

Gadamer, H.-G., 1979, Truth and method, Sheed \& Ward, London.

Goosen, D.P., 2017, 'Die metafisiese tradisie vandag. 'n Interpretasie van Eric D. Perl', Litnet Akademies 14(3), 557-591.

Gracia, J.J.E., 2006, 'Philosophy in the middle ages: An introduction', in J.J.E. Gracia \& T.B. Noone (eds.), 2006, A companion to philosophy in the Middle Ages, pp. 1-14, Blackwell, Oxford. https://doi.org/10.1002/9780470996669.ch1

Habermas, J., 1987, The philosophical discourse of modernity: Twelve lectures, The MIT Press, Cambridge, MA

Heidegger, M., 1958, Introduction to metaphysics, transl. R. Mannheim, Yale University Press, New Haven, CT.

Jameson, F., 1984, 'Foreword', in J.-F. Lyotard (ed.), The postmodern condition, pp. i-xxv, Manchester University Press, Manchester.

Jameson, F, 1992, Postmodernism, or the cultural logic of late capitalism, Duke University Press, Durham. https://doi.org/10.1215/9780822378419

Jameson, F., 2002, A singular modernity: Essays on the ontology of the present, Verso, London.

Lyotard, J-F., 1984, The postmodern condition, transl. M. Bennington \& B. Massumi, Manchester University Press, Manchester.

Nietzsche, F.W., 1886 [1968], Jenseits von Gut und Böse, in G. Colli \& M. Montinari (eds.), Nietzsche Werke, Kritische Gesamtausgabe, NW VI (2), pp. 3-255, Walter de Gruyter, Berlin.

Norris, C., 1993, The truth about postmodernism, Blackwell, Oxford.

Norris, C., 1997, Deconstruction: Theory and practice. Routledge, London.

Norris, C., 1998, What's wrong with postmodernism: Critical theory and the ends of philosophy, John Hopkins University Press, Baltimore, MD.

Perl, E.D., 2007, Theophany: The neoplatonic philosophy of Dionysius the Areopagite, State University of New York Press, Albany, NY

Virilio, P., 2002, Ground zero, transl. C. Turnzer, Verso, London.

Watts, V.E. (transl.), 1998, Boethius: The consolation of philosophy, The Folio Society, London.

Zizek, S., 2002, Welcome to the desert of the real: Five essays on September 11 and related dates, Verso, London. 